\title{
Aggravated phosphorus limitation on biomass production under increasing nitrogen loading: a meta-analysis
}

\author{
YONG LI, SHULI NIU and GUIRUI YU \\ Key Laboratory of Ecosystem Network Observation and Modeling, Institute of Geographic Sciences and Natural Resources \\ Research, Chinese Academy of Sciences, Beijing 100101, China
}

\begin{abstract}
Nitrogen $(\mathrm{N})$ and phosphorus $(\mathrm{P})$, either individually or in combination, have been demonstrated to limit biomass production in terrestrial ecosystems. Field studies have been extensively synthesized to assess global patterns of $\mathrm{N}$ impacts on terrestrial ecosystem processes. However, to our knowledge, no synthesis has been done so far to reveal global patterns of $\mathrm{P}$ impacts on terrestrial ecosystems, especially under different nitrogen (N) levels. Here, we conducted a meta-analysis of impacts of $\mathrm{P}$ addition, either alone or with $\mathrm{N}$ addition, on aboveground (AGB) and belowground biomass production (BGB), plant and soil P concentrations, and N : P ratio in terrestrial ecosystems. Overall, our meta-analysis quantitatively confirmed existing notions: (i) colimitation of $\mathrm{N}$ and $\mathrm{P}$ on biomass production and (ii) more P limitation in tropical forest than other ecosystems. More importantly, our analysis revealed new findings: (i) P limitation on biomass production was aggravated by $\mathrm{N}$ enrichment and (ii) plant $\mathrm{P}$ concentration was a better indicator of P limitation than soil P availability. Specifically, P addition increased AGB and BGB by $34 \%$ and $13 \%$, respectively. The effect size of $\mathrm{P}$ addition on biomass production was larger in tropical forest than grassland, wetland, and tundra and varied with $\mathrm{P}$ fertilizer forms, $\mathrm{P}$ addition rates, or experimental durations. The P-induced increase in biomass production and plant $\mathrm{P}$ concentration was larger under elevated than ambient N. Our findings suggest that the global limitation of $\mathrm{P}$ on biomass production will become severer under increasing $\mathrm{N}$ fertilizer and deposition in the future.
\end{abstract}

Keywords: aboveground biomass production, belowground biomass production, global synthesis, P limitation, plant N concentration, plant $\mathrm{P}$ concentration, terrestrial ecosystem

Received 18 June 2015; revised version received 7 September 2015 and accepted 13 September 2015

\section{Introduction}

Nitrogen $(\mathrm{N})$ and phosphorus $(\mathrm{P})$ have been considered the most limited nutrients for terrestrial ecosystem productivity (Elser et al., 2007; Vitousek et al., 2010; Harpole et al., 2011), although the relative importance of $\mathrm{N}$ and $\mathrm{P}$ limitation has been in open debate (Tyrrell, 1999; Elser et al., 2007; Vitousek et al., 2010). The traditional concept is that terrestrial ecosystem productivity is primarily $\mathrm{N}$ limited (Lebauer \& Treseder, 2008), but may be colimited by P (Elser et al., 2007; Harpole et al., 2011). Unlike the massive amount and multiple ways of human-caused reactive nitrogen input to ecosystems, the only source of atmosphere phosphorus deposition is through dust and flying ash from wildfires, which is small in amount and difficult for plants to directly uptake (Mahowald et al., 2008). Thus, the unbalanced human-induced $\mathrm{N}$ and $\mathrm{P}$ inputs into the biosphere are expected to drive terrestrial ecosystems toward more $\mathrm{P}$ limitation (Vitousek et al., 2010; Peñuelas et al., 2013). However, it is still not well characterized that if, where,

Correspondence: Shuli Niu, tel. +86 106488 8062, fax +86 106486 8962, e-mail: sniu@igsnrr.ac.cn how, and by how much $\mathrm{P}$ limits biomass production, and whether $\mathrm{P}$ will become more limited under enriched $\mathrm{N}$ condition.

Case studies have been conducted to examine responses of ecosystem biomass production to $\mathrm{P}$ addition, which vary significantly among different studies or ecosystems (Davidson et al., 2004; Huang et al., 2012). For instance, biomass has been reported to increase (Herbert \& Fownes, 1995; Güsewell et al., 2003), decrease (Bennett \& Adams, 2001; Corbin et al., 2003), or to change insignificantly (Soudzilovskaia et al., 2005) in response to external $P$ input. The various results may be due to different ecosystem types, $\mathrm{P}$ fertilizer forms, or $\mathrm{P}$ addition rates. For example, tropical forest is well documented to be more P limited than other ecosystems because of its highly weathered soils (Cleveland et al., 2002; Vitousek, 2004; Elser et al., 2007; Townsend et al., 2007). P addition rates may also influence ecosystem responses, with stronger responses under more $\mathrm{P}$ input. However, to our knowledge, no global synthesis has been conducted so far to reveal any generalizable patterns and regulatory factors of terrestrial ecosystem biomass production in responses to $\mathrm{P}$ addition. The lack of a global analysis of ecosystem 
responses to $\mathrm{P}$ limitation significantly limits our ability in predicting how the $\mathrm{P}$ limitation on terrestrial $\mathrm{C}$ production will change under future climate conditions.

Soil $\mathrm{P}$ is often unavailable to plant uptake although the total amount of $\mathrm{P}$ in soil might be high (Schachtman et al., 1998). Thus, external $P$ addition usually increases soil $\mathrm{P}$ availability, plant $\mathrm{P}$ concentration, photosynthesis, and thus biomass production (Schachtman et al., 1998; Garg et al., 2004; Graciano et al., 2006; Burman et al., 2009; Reich et al., 2009; Suriyagoda et al., 2014). However, which variable is more indicative of $P$ limitation to biomass production has been debated. Some studies demonstrated that plant $\mathrm{N}$ : P ratios can better indicate $\mathrm{N}$ or $\mathrm{P}$ limitation than plant $\mathrm{N}$ and $\mathrm{P}$ concentrations (Güsewell, 2004; Agren, 2008). Other studies explored relationships between soil or leaf $\mathrm{P}$ concentration with biomass production (Reich et al., 2009). It still needs to be further evaluated how well P-induced biomass change is indicated by leaf $\mathrm{P}$, soil $\mathrm{P}$ availability, or $\mathrm{N}$ : P ratio across terrestrial ecosystems.

The objective of this study was to assess effects of $P$ addition on biomass production, plant and soil $\mathrm{N}$ and $\mathrm{P}$ concentrations, and $\mathrm{N}$ : $\mathrm{P}$ ratio under different ecosystem types, fertilizer forms and rates, and experimental durations. We conducted a meta-analysis of results from field experiments on responses of aboveground (AGB) and belowground biomass production (BGB) to manipulative $\mathrm{P}$ addition under ambient and enriched $\mathrm{N}$ conditions. The specific questions this synthesis addressed were as follows: (i) What are the global patterns of the responses of terrestrial biomass production, plant and soil $\mathrm{N}$ and $\mathrm{P}$ concentrations, and $\mathrm{N}$ : $\mathrm{P}$ ratios to $\mathrm{P}$ addition? (ii) Whether $\mathrm{P}$ limitation is enhanced under increased $\mathrm{N}$ loading? and (iii) Whether the Pinduced increase in ecosystem biomass production is correlated with changes in soil $\mathrm{P}$ availability, leaf $\mathrm{P}$ concentration, or N : P ratio?

\section{Materials and methods}

\section{Data selection}

Peer-reviewed publications were searched using Web of Science to build a compiled database, which included the responses to $\mathrm{P}$ addition of different variables related to plant biomass production, plant $\mathrm{N}$ and $\mathrm{P}$ concentrations, and soil available $\mathrm{N}$ and $\mathrm{P}$ concentrations. The following criteria were applied to select appropriate studies: (i) Measurements and data were only collected from field manipulative experiments of $\mathrm{P}$ addition that conducted in natural terrestrial ecosystems. (ii) The examined variables were plant biomass production at the community level, plant $\mathrm{N}$ and $\mathrm{P}$ concentration, and soil $\mathrm{N}$ and $\mathrm{P}$ concentration. (iii) When data from the same site were presented in multiple publications, a single measurement from the latest sample date was used to meet the statistical assumption of independence among observations. Finally, 65 papers on 50 experiments including 45 with $\mathrm{N}+\mathrm{P}$ addition and five with $\mathrm{P}$ addition alone were selected in this study (Table S1).

Three groups of data related to plant biomass production and N, P concentration were extracted from the literatures: (i) plant biomass production, including aboveground biomass production (AGB; leaf, wood, shoot), BGB (root, fine root), aboveground and belowground net primary production, and the ratios of $\mathrm{AGB}$ : $\mathrm{BGB}$; (ii) plant $\mathrm{N}$ and $\mathrm{P}$ concentration and $\mathrm{N}: \mathrm{P}$ ratio; (iii) soil available $\mathrm{N}$ and $\mathrm{P}$ concentration. When data (means and measures of variance) were presented in the form of graphs, the figures were digitized to extract the numerical values using Engauge Digitizer (Free Software Foundation, Inc., Boston, MA, USA). In addition, we collected other background information, such as mean annual temperature and mean annual precipitation at each study site. We divided these data into two datasets: dataset I included only $\mathrm{P}$ addition without $\mathrm{N}$ addition in combination, and dataset II contained studies on $\mathrm{P}$ addition together with $\mathrm{N}$ addition. In dataset II, there were usually four treatments: control, $\mathrm{P}$ addition, $\mathrm{N}$ addition, and $\mathrm{N}+\mathrm{P}$ addition. The effect size of $\mathrm{P}$ addition was calculated by referring $\mathrm{N}$ addition treatment as control and the combined treatment ( $\mathrm{P}$ plus $\mathrm{N}$ addition) as the $\mathrm{P}$ addition treatment. In order to compare the relative impacts of $\mathrm{N}$ addition vs. $\mathrm{P}$ addition, we also calculated effect sizes of $\mathrm{N}$ addition in dataset II. In order to examine how ecosystem types, P treatments and experimental periods influence the response ratio of $\mathrm{P}$ addition, we grouped the data according to ecosystem types (forest, grassland, wetland, and tundra), $\mathrm{P}$ application forms $\left[\mathrm{Ca}\left(\mathrm{H}_{2} \mathrm{PO} 4\right)_{2}\right.$ and $\left.\mathrm{NaH}_{2} \mathrm{PO}_{4}\right], \mathrm{P}$ application rates $(<5$, 5-10, 10-15 and $>15 \mathrm{~g} \mathrm{~m}^{-2} \mathrm{yr}^{-1}$ ), and experimental durations ( $\leq 3$ and $>3$ years). Since almost all the $\mathrm{P}$ addition experiments on forests were limited to tropical forests, we only have the results from one forest biome type for this study.

\section{Meta-analysis}

The meta-analysis was conducted using the techniques described in Hedges et al. (1999). The effect size of $P$ addition treatment for each individual observation was estimated by the response ratio, $R R=\bar{X}_{t} / \bar{X}_{c}$, where $\bar{X}_{t}$ is the treatment mean, and $\bar{X}_{\mathrm{c}}$ is the control mean. More specifically, the mean, standard deviation $(S)$ or standard error, and sample size for each observation were extracted to calculate the RR, the variance $(v)$, the weighting factor $\left(w_{i j}\right)$, the weighted response ratio $\left(R R_{++}\right)$, and the $95 \%$ confidence interval $(C I)$ of $R R_{++}$for the purpose of statistic tests. Those variables were calculated as following:

$$
v=0.188 \times\left(\frac{\left(\mathrm{SD}_{\mathrm{c}}\right)^{2}}{N_{\mathrm{c}} \bar{X}_{\mathrm{c}}^{2}}\right)+\left(\frac{\left(\mathrm{SD}_{\mathrm{t}}\right)^{2}}{\left(N_{\mathrm{t}} \bar{X}_{\mathrm{t}}^{2}\right.}\right)
$$

where $\mathrm{SD}_{\mathrm{c}}$ and $\mathrm{SD}_{\mathrm{t}}$ are the standard deviations of the control treatment and $\mathrm{P}$ addition treatment; and $N_{\mathrm{c}}$ and $N_{\mathrm{t}}$ are the sample sizes of the control treatment and $\mathrm{P}$ addition treatment, respectively. 


$$
\begin{gathered}
w_{i j}=\frac{1}{v} \\
\mathrm{RR}_{++}=\frac{\sum_{i=1}^{m} \sum_{j=1}^{k j} w_{i j} \mathrm{RR}_{i j}}{\sum_{i=1}^{m} \sum_{j=1}^{k j} w_{i j}} \\
S\left(\mathrm{RR}_{++}\right)=\sqrt{\frac{1}{\sum_{i=1}^{m} \sum_{j=1}^{k j} w_{i j}}} \\
95 \% \mathrm{CI}=\mathrm{RR}_{++} \pm 1.96 \mathrm{~S}(\mathrm{RR})_{++}
\end{gathered}
$$

Relevant detailed information is presented in Hedges et al. (1999). Using the METAWIN software 2.1 (Sinauer Associates, Inc. Sunderland, MA, USA), we calculated the above variables. If the lower bound of the $95 \% \mathrm{CI}$ of $\mathrm{RR}_{++}$was larger than 1 , then the response was considered significantly positive at $P<0.05$. If the upper bound of the $95 \% \mathrm{CI}$ of $\mathrm{RR}_{++}$was smaller than 1 , then the response was considered significantly negative at $P<0.05$.

To further examine how various ecosystem types and treatments affect $\mathrm{P}$ addition effects, the data were categorized as described in the above section. Total heterogeneity among group $\left(Q_{t}\right)$ was partitioned into within-group heterogeneity $\left(Q_{\mathrm{w}}\right)$ and between group heterogeneity $\left(Q_{\mathrm{b}}\right)$. According to (Hedges et al., 1999), significance of $Q_{\mathrm{b}}$ indicated that the response ratios are different among different subgroups. Means of the subgroups were considered significantly different with each other if their 95\% CI did not overlap.

\section{Statistic analysis}

To examine whether $\mathrm{N}$ addition will stimulate $\mathrm{P}$ limitation, we compare the effect size of $\mathrm{P}$ addition between the groups of with or without $\mathrm{N}$ addition. $t$-Test was used to test the statistic differences. The statistic differences between the effect sizes of $\mathrm{P}$ addition and that of $\mathrm{N}$ addition were also analyzed by $t$-test. We used the linear regression methods to analyze the relationships of biomass response ratios with the response ratios of soil $\mathrm{P}$ availability, leaf $\mathrm{P}$ concentration, soil and plant $\mathrm{N}: \mathrm{P}$ ratios. The regression analysis was conducted with the SPSS software (SPSS 11.0 for windows; SPSS Inc., Chicago, IL, USA), and the graphs were drawn with the SIGMAPLOT software (SIGMAPLOT 12.5 for windows; Systat Software Inc., San Jose, CA, USA).

\section{Results}

Effects of $P$ addition in comparison with the effects of $N$ addition

Across all the studies, phosphorus $(\mathrm{P})$ addition significantly increased AGB, BGB and AGB : BGB ratio on average by $34 \%, 13 \%$ and $32 \%$, respectively. The effect sizes of $\mathrm{P}$ addition were not significantly different from that of $\mathrm{N}$ addition on AGB $(P=0.20)$ and BGB $(P=0.07)$, but were significantly lower on AGB : BGB than that of $\mathrm{N}$ addition $(P=0.01)$ (Fig. 1). $\mathrm{P}$ addition increased plant $\mathrm{P}$ concentration by $72 \%$ but reduced plant $\mathrm{N}$ concentration and $\mathrm{N}: \mathrm{P}$ ratio by $3 \%$ and $45 \%$, respectively (all $P<0.05$ ). However, $\mathrm{N}$ addition reduced plant $\mathrm{P}$ concentration by $8 \%$ and increased plant N concentration and N : P ratio by $24 \%$ and $25 \%$, respectively (Fig. 1, all $P<0.05$ ). $\mathrm{P}$ addition had no significant effect on soil available $\mathrm{N}$ concentration but increased soil available $\mathrm{P}$ concentration, whereas $\mathrm{N}$ addition increased soil available $\mathrm{N}$ concentration and had no significant effect on soil available P concentration (Fig. 1).

\section{Effects of $P$ addition on biomass production}

In general, $\mathrm{P}$ addition increased AGB by $32 \%$ under ambient $\mathrm{N}$ and by $36 \%$ under elevated $\mathrm{N}$ (all $P<0.05$, Fig. 2). There was significant difference in response ratio among ecosystem types $(P<0.01$, Fig. 2a). In tropical forest, $P$ addition increased AGB by $92 \%$ and $32 \%$, respectively, under ambient and elevated $\mathrm{N}$ condition. In grassland, $\mathrm{P}$ addition increased AGB by $30 \%$ with $\mathrm{N}$ addition, but did not significantly change AGB without $\mathrm{N}$ addition. In tundra, $\mathrm{P}$ addition had no significant effect on AGB either with or without $\mathrm{N}$ addition. $\mathrm{AGB}$ in wetland was more increased by $\mathrm{P}$ addition with $\mathrm{N}(44 \%)$ than without $\mathrm{N}(21 \%)$ application (Fig. 2a, b). The increase of AGB was significant for $\mathrm{Ca}\left(\mathrm{H}_{2} \mathrm{PO}_{4}\right)_{2}$ but not for $\mathrm{NaH}_{2} \mathrm{PO}_{4}$ application without $\mathrm{N}$ addition. However, with $\mathrm{N}$ addition, the response ratios were significant for both $\mathrm{Ca}\left(\mathrm{H}_{2} \mathrm{PO}_{4}\right)_{2}$ and $\mathrm{NaH}_{2} \mathrm{PO}_{4}$ addition. AGB was significantly increased by any $\mathrm{P}$ addition rates under both ambient and elevated $\mathrm{N}$ condition, but the increase was larger in the rate of $>15 \mathrm{~g} \mathrm{~m}^{-2}$ than other rates under ambient $\mathrm{N}$ (Fig. 2). The $\mathrm{P}$ addition effect was not significantly different between experimental durations under either ambient or elevated $\mathrm{N}$ addition ( $P>0.05$, Fig. 2$)$.

Phosphorus addition increased BGB by an average of $14 \%$ under ambient $\mathrm{N}$, but did not significantly change it under elevated $\mathrm{N}$ addition (Fig. 3). For different ecosystem types, $\mathrm{P}$ addition under ambient $\mathrm{N}$ significantly increased BGB in tropical forest, but not in any other ecosystems. P addition had no significant effect on BGB in any ecosystems except grassland under elevated $\mathrm{N}$ addition (Fig. 3b). The increase of $\mathrm{BGB}$ was not significant for $\mathrm{Ca}\left(\mathrm{H}_{2} \mathrm{PO}_{4}\right)_{2}$ or $\mathrm{KH}_{2} \mathrm{PO}_{4}$ application without $\mathrm{N}$ addition, but was significant for $\mathrm{KH}_{2} \mathrm{PO}_{4}$ application with $\mathrm{N}$ addition.

Overall, $\mathrm{P}$ addition effect on AGB : BGB was stronger under elevated than ambient $\mathrm{N}$ condition (Fig. 4). Specifically, AGB : BGB ratio was not significantly changed by $\mathrm{P}$ addition alone, but was increased by 


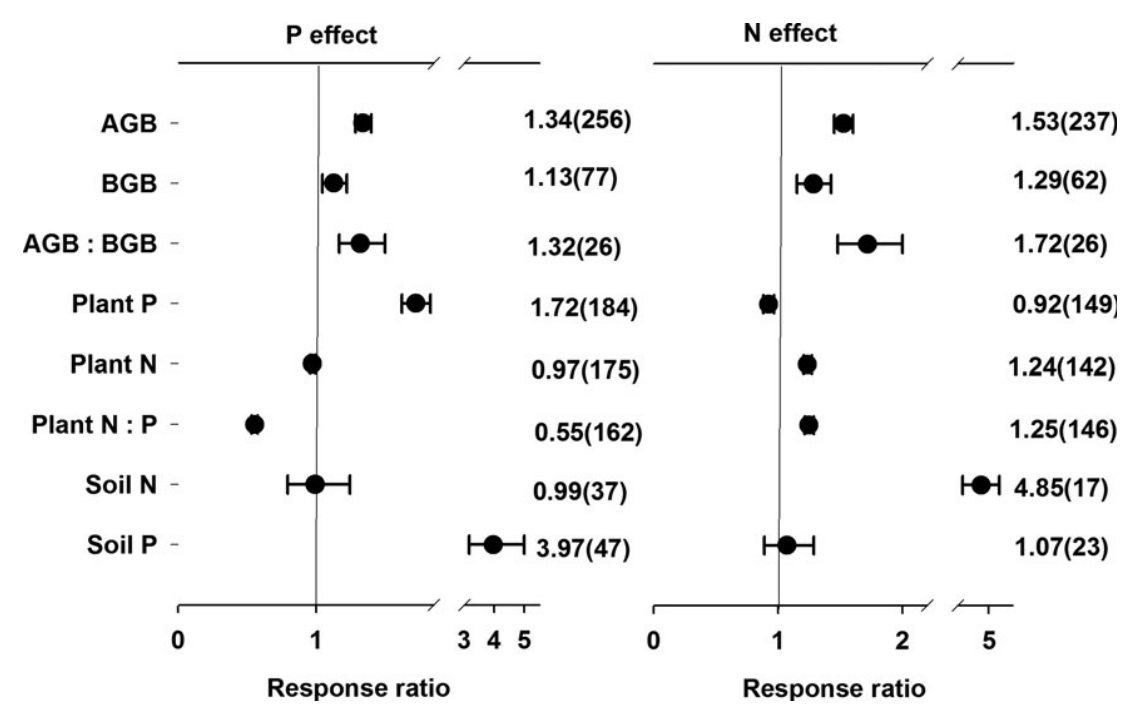

Fig. 1 Effects of phosphorus $(\mathrm{P})$ addition and nitrogen $(\mathrm{N})$ addition on aboveground biomass production (AGB), belowground biomass production (BGB), AGB : BGB, plant $\mathrm{N}$ and $\mathrm{P}$ concentrations, and $\mathrm{N}: \mathrm{P}$, soil $\mathrm{N}$ and $\mathrm{P}$ concentrations. The numbers outside and inside parentheses represent response ratio and the number of observations. The dots with error bars indicate the mean effect size with the $95 \%$ CI.

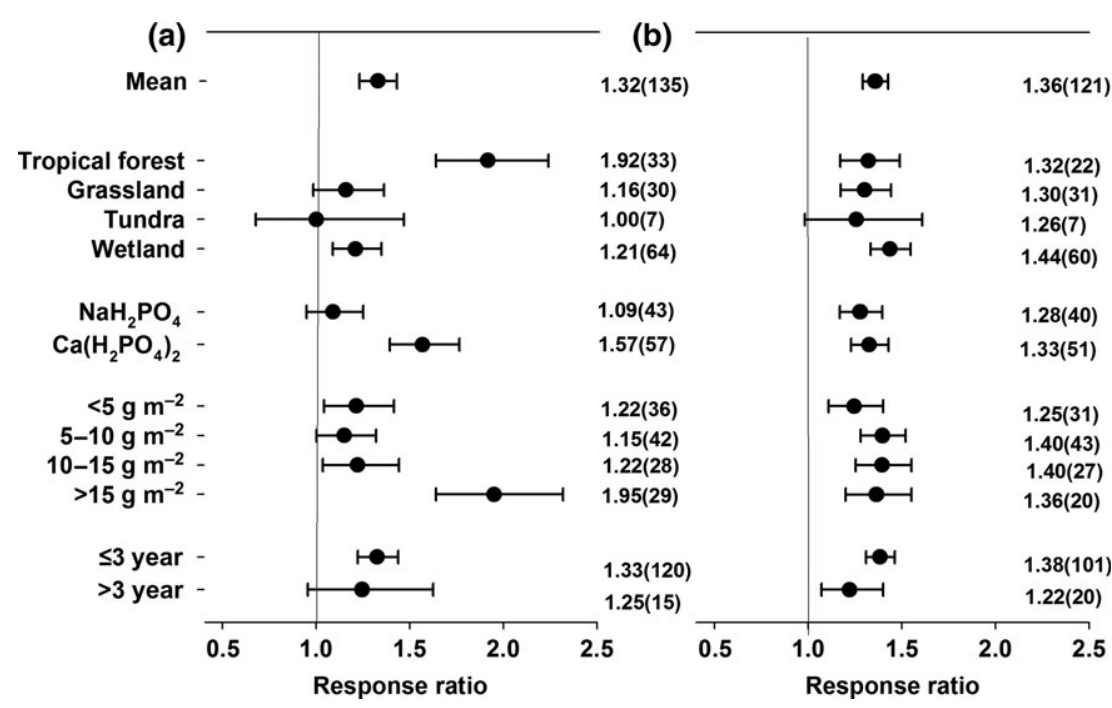

Fig. 2 Phosphorus (P) addition effects on aboveground biomass production under ambient (a) and elevated (b) nitrogen (N) conditions. The numbers outside and inside parentheses represent response ratio and the number of observations. The dots with error bars indicate the mean effect size with the $95 \% \mathrm{CI}$.

47\% under $\mathrm{P}$ addition with $\mathrm{N}$ addition (Fig. 4b). For different ecosystem types, $\mathrm{P}$ addition alone significantly increased AGB : BGB only in wetland, but P addition with $\mathrm{N}$ addition significantly increased it for all ecosystem types except tundra. The P-induced increase in AGB : BGB was significant for $\mathrm{Ca}\left(\mathrm{H}_{2} \mathrm{PO}_{4}\right)_{2}$ but not for $\mathrm{NaH}_{2} \mathrm{PO}_{4}$ under ambient $\mathrm{N}$. Under elevated $\mathrm{N}$ condition, $\mathrm{P}$ addition increased $\mathrm{AGB}$ : $\mathrm{BGB}$ significantly for both $\mathrm{KH}_{2} \mathrm{PO}_{4}$ and $\mathrm{Ca}\left(\mathrm{H}_{2} \mathrm{PO}_{4}\right)_{2}$. $\mathrm{P}$ addition effect had no significant difference between
$\mathrm{P}$ application rates under either ambient or elevated $\mathrm{N}$ condition.

\section{Effects of $P$ addition on plant $N$ and $P$ concentrations}

Across all studies, $\mathrm{P}$ addition increased plant $\mathrm{P}$ concentration by $61 \%$ without $\mathrm{N}$ and $90 \%$ with $\mathrm{N}$ addition (Fig. 5). The increase on plant $\mathrm{P}$ concentration was significant for all ecosystem types and was mostly pronounced for tundra. For different $\mathrm{P}$ fertilizers, the 


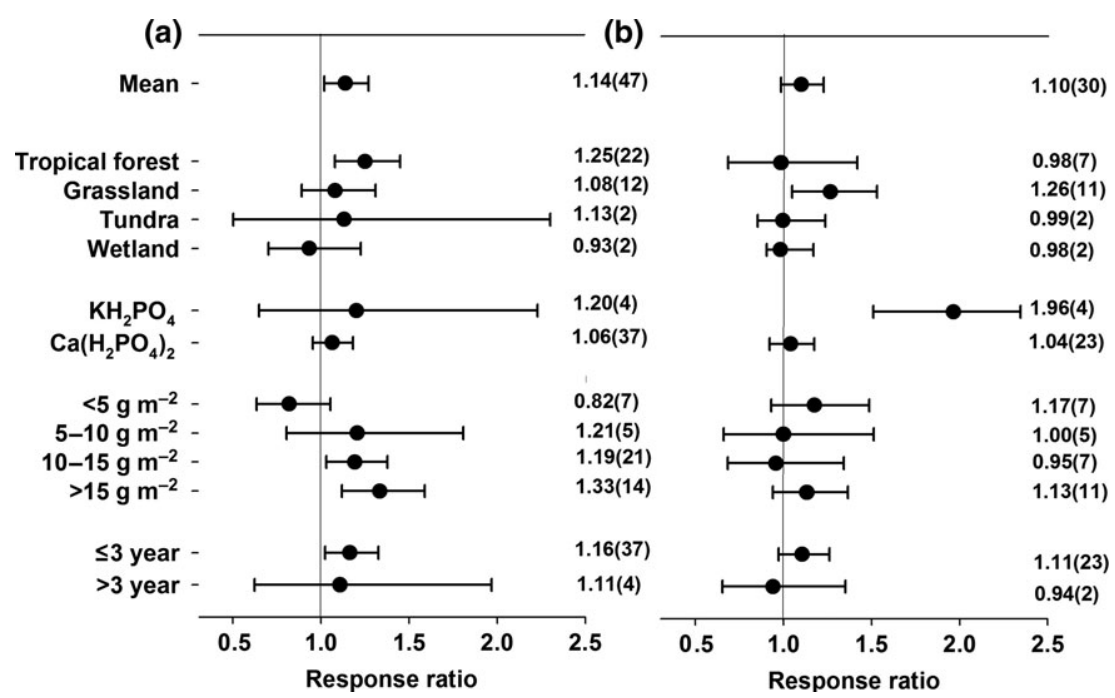

Fig. 3 Phosphorus (P) addition effects on belowground biomass production under ambient (a) and elevated (b) nitrogen (N) conditions. The numbers outside and inside parentheses represent response ratio and the number of observations. The dots with error bars indicate the mean effect size with the $95 \% \mathrm{CI}$.

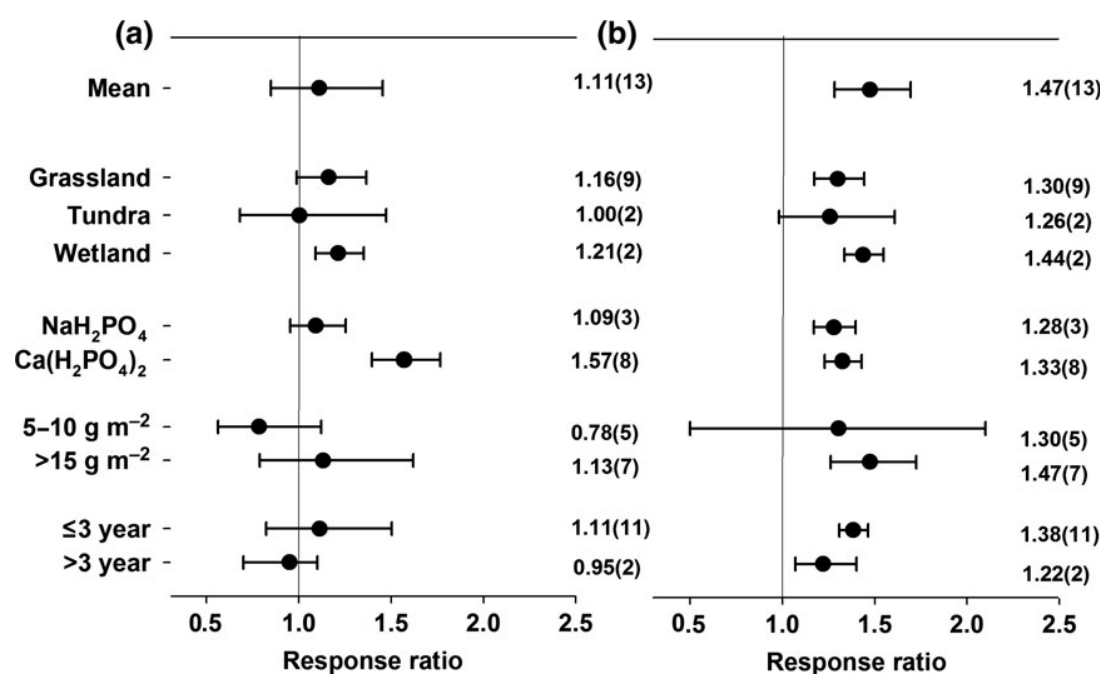

Fig. 4 Phosphorus (P) addition effects on the ratios of aboveground: belowground biomass production under ambient (a) and elevated (b) nitrogen $(\mathrm{N})$ conditions. The numbers outside and inside parentheses represent response ratio and the number of observations. The dots with error bars indicate the mean effect size with the 95\% CI.

increase was significant for $\mathrm{NaH}_{2} \mathrm{PO}_{4}$ and $\mathrm{Ca}\left(\mathrm{H}_{2} \mathrm{PO}_{4}\right)_{2}$ without $\mathrm{N}$ addition and was only significant for $\mathrm{Ca}$ $\left(\mathrm{H}_{2} \mathrm{PO}_{4}\right)_{2}$ with $\mathrm{N}$ addition. Plant $\mathrm{P}$ concentration was significantly increased by any $\mathrm{P}$ addition rates. The increase was stronger with $>3$ years than $<3$ years studies. Moreover, there were significant differences among plant types $(P<0.01$, Fig. $5 \mathrm{a}, \mathrm{b})$, with herbaceous plants responded more than woody plants.

Plant N : P ratio was significantly decreased by $\mathrm{P}$ addition on average by $40 \%$ without $\mathrm{N}$ and $50 \%$ with $\mathrm{N}$ addition (Fig. 6). The P addition effect on N : P ratio was significant for all ecosystem types and mostly pronounced in tundra, under both ambient and elevated $\mathrm{N}$ condition. The decrease of $\mathrm{N}: \mathrm{P}$ was also significant for all $\mathrm{P}$ addition rates and experimental periods. Plant N : P was decreased more in herbaceous than woody plants under $\mathrm{P}$ addition without or with $\mathrm{N}$ addition (Fig. 6).

\section{Effects of $P$ addition on soil $P$ and $N$ concentration}

Across all studies, $\mathrm{P}$ addition increased soil available P concentration by an average of $297 \%$ but had no significant effect on soil available $\mathrm{N}$ concentration 


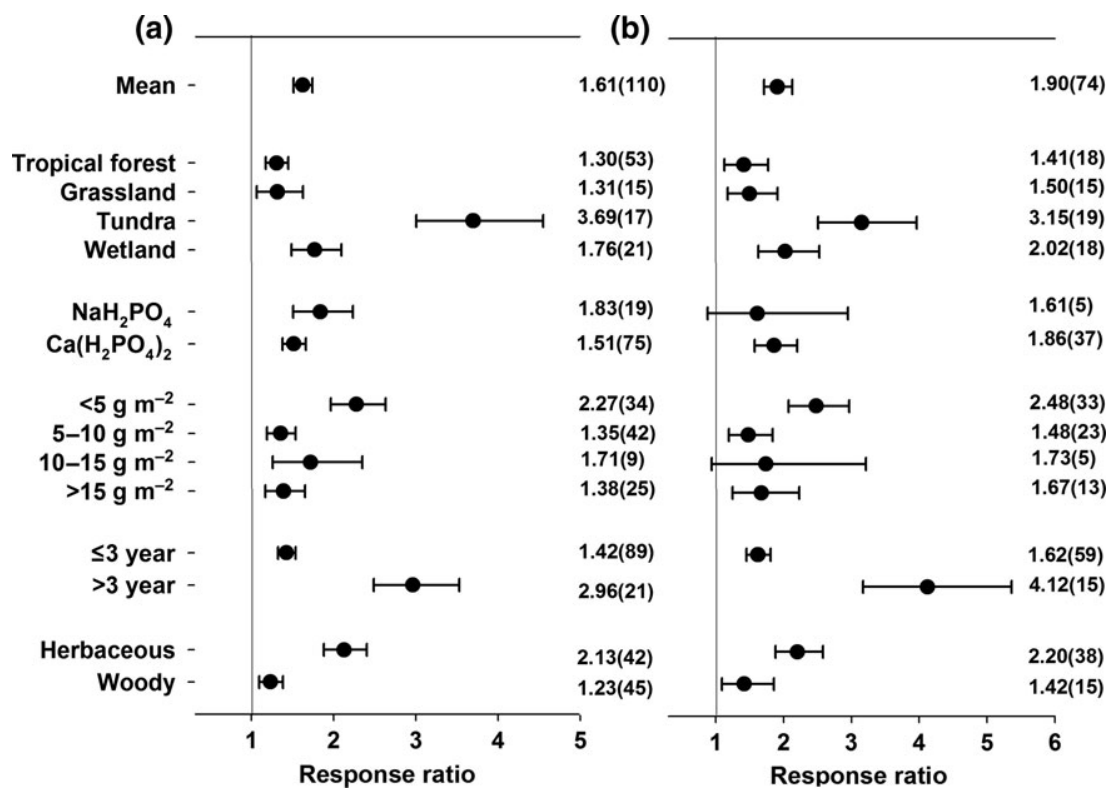

Fig. 5 Phosphorus (P) addition effects on plant $\mathrm{P}$ concentration under ambient (a) and elevated (b) nitrogen (N) conditions. The numbers outside and inside parentheses represent response ratio and the number of observations. The dots with error bars indicate the mean effect size with the $95 \%$ CI.

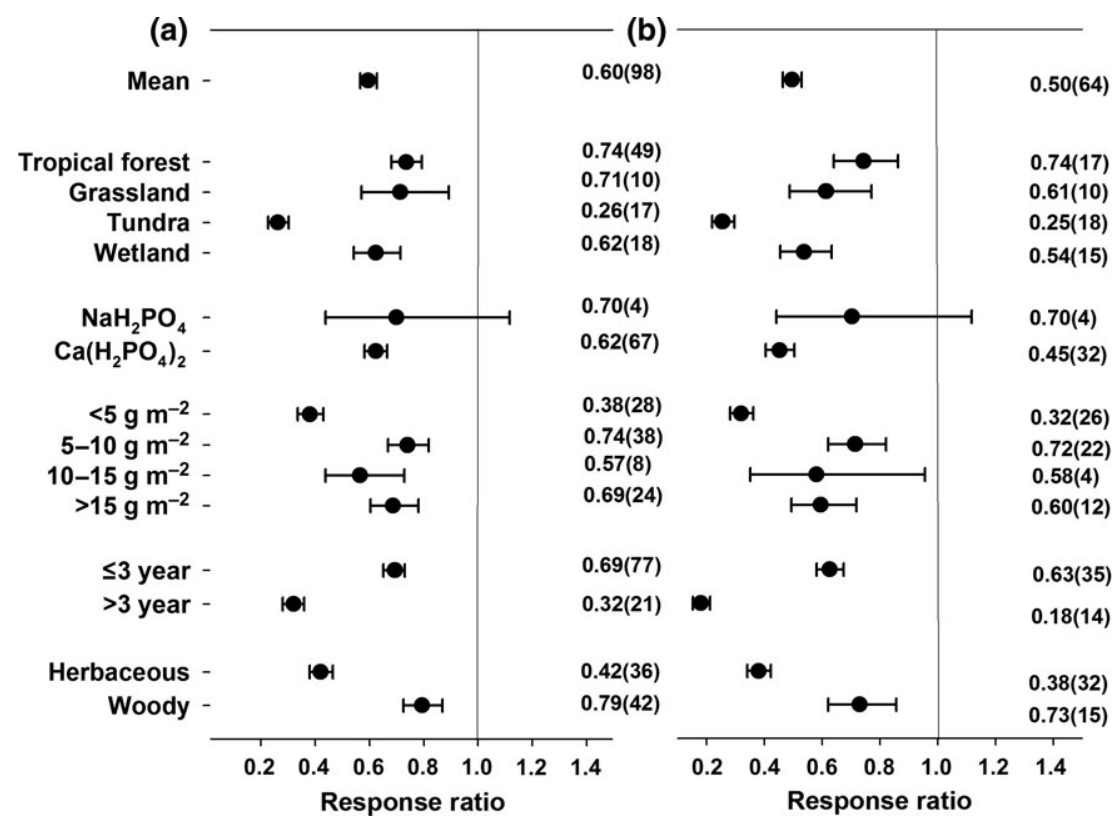

Fig. 6 Phosphorus (P) addition effects on plant N : P under ambient (a) and elevated (b) nitrogen (N) conditions. The numbers outside and inside parentheses represent response ratio and the number of observations. The dots with error bars indicate the mean effect size with the $95 \%$ CI.

(Fig. 7). When data were subdivided into ecosystem types, $\mathrm{P}$ addition was most pronounced for tropical forest $(374 \%)$, which is significantly greater than that for tundra (185\%). P addition effect was larger in the form of $\mathrm{NaH}_{2} \mathrm{PO}_{4}$ (567\%) than $\mathrm{Ca}\left(\mathrm{H}_{2} \mathrm{PO}_{4}\right)_{2} \quad(245 \%)$ and increased with $\mathrm{P}$ addition rates (Fig. 7). P addition had no significant effect on soil available $\mathrm{N}$ concentration for any ecosystem types, $\mathrm{P}$ fertilizer types, application levels or experimental durations (Fig. 7). 


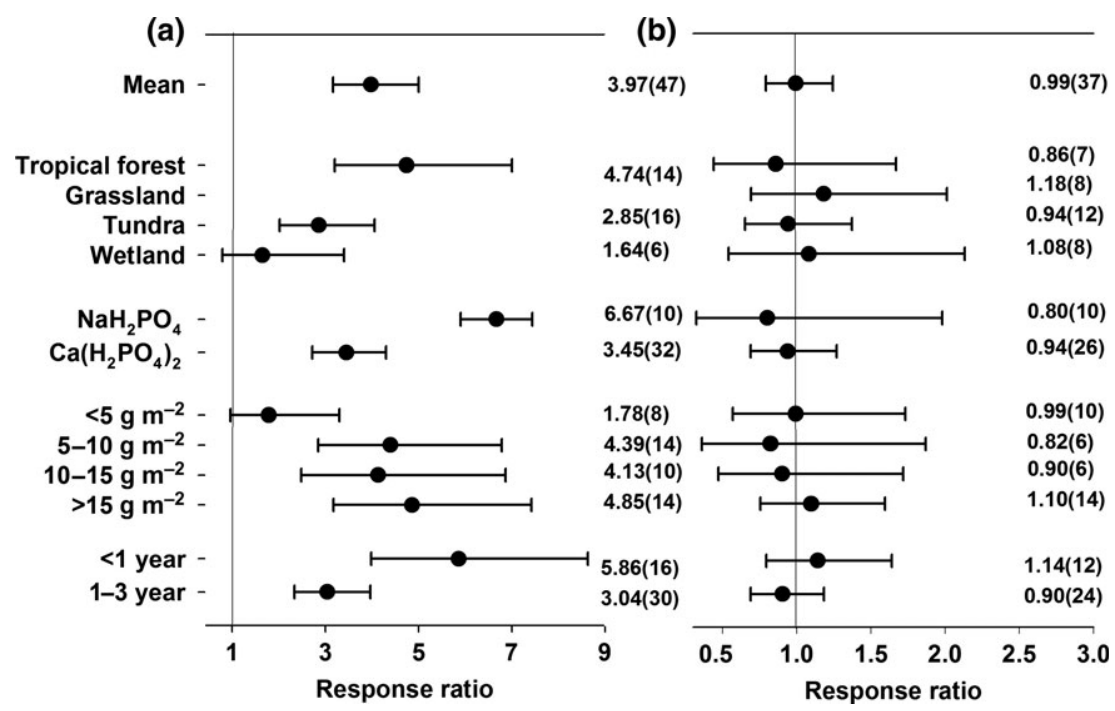

Fig. 7 Phosphorus (P) addition effects on soil available $\mathrm{P}(\mathrm{a})$ and nitrogen (N) (b) concentrations. The numbers outside and inside parentheses represent response ratio and the number of observations. The dots with error bars indicate the mean effect size with the $95 \%$ CI.
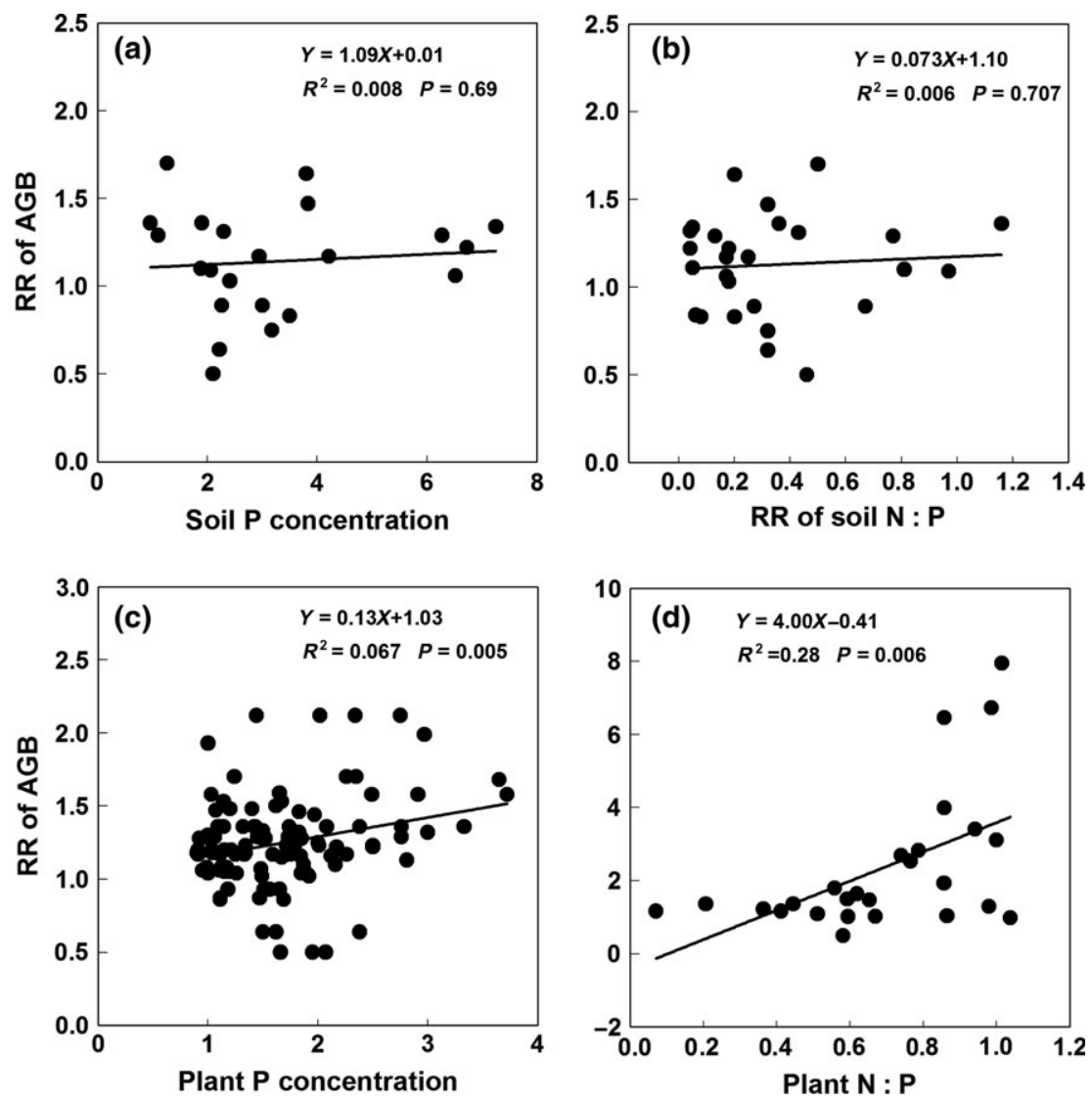

Fig. 8 Relationships of the response ratio (RR) of aboveground biomass production (AGB) with the changes in soil phosphorus (P) availability (a), soil available $\mathrm{N}$ : P ratio (b), plant P concentration (c) and N : P ratio (d).

The response ratio of biomass production was not significantly correlated with the changes in soil $\mathrm{P}$ availability (Fig. 8a), or soil N : P ratio (Fig. 8b), but was significantly correlated with the changes in plant $\mathrm{P}$ concentration and $\mathrm{N}: \mathrm{P}$ ratio (Fig. 8c, d). 


\section{Discussion}

Phosphorus limitation and its aggravation under enriched $N$

It has been shown before that terrestrial biomass production is primarily limited by $\mathrm{N}$ or colimited by $\mathrm{N}$ and P (Elser et al., 2007; Lebauer \& Treseder, 2008; Harpole et al., 2011). By synthesizing results from field $P$ addition experiments, we found that biomass production significantly increased with $\mathrm{P}$ addition. The effect size of $\mathrm{P}$ addition was not significantly different from that of $\mathrm{N}$ addition $(P>0.05)$, indicating the colimitation of $\mathrm{P}$ and $\mathrm{N}$ for biomass production in terrestrial ecosystems. This significant $\mathrm{P}$ limitation on terrestrial biomass production can be caused by soil physical or chemical mechanisms, such as soil depletion, soil barrier, low-P parent material, anthropogenic limitation (Vitousek et al., 2010), or the modification of P cycling induced by human activity (Benner \& Vitousek, 2007; Vitousek et al., 2010). Our results support a conclusion by Elser et al. (2007) on the $\mathrm{N}$ and $\mathrm{P}$ colimitation but offer new insights into mechanisms underlying P-induced changes in biomass production. The findings suggest that the ongoing human-caused changes in $\mathrm{N}$ and $\mathrm{P}$ inputs will substantially alter the dynamics of terrestrial biomass.

Our study indicates that the P limitation in terrestrial ecosystems is aggravated under the increased $\mathrm{N}$ level according to two lines of evidence. First, $\mathrm{N}$ addition significantly decreased plant $\mathrm{P}$ concentrations and increased plant N : P ratios (Fig. 1b). The P-induced increases in plant $\mathrm{P}$ concentrations were larger under elevated than ambient $\mathrm{N}$ (Fig. 5). $\mathrm{N}$ addition stimulates plant growth so that demand for $\mathrm{P}$ increases. Consequently, P limitation became more apparent under elevated than ambient $\mathrm{N}$ levels as indicated by significantly decreased plant $\mathrm{P}$ concentration and increased $\mathrm{N}: \mathrm{P}$ ratio. The shift toward $\mathrm{P}$ limitation under $\mathrm{N}$ addition has been observed in forests (Gress et al., 2007; Braun et al., 2010) and lakes (Elser et al., 2007; Crowley et al., 2012). This study offered evidence that $\mathrm{P}$ limitation under $\mathrm{N}$ enrichment was globally distributed in all types of terrestrial ecosystems except tundra.

Nitrogen enrichment was previously reported to increase phosphatase activity and thus soil $\mathrm{P}$ availability (Olander \& Vitousek, 2000). More extracellular phosphatase enzymes were produced under $\mathrm{N}$ addition or in the presence of $\mathrm{N}_{2}$-fixing plants owing to the higher ability of investing $\mathrm{N}$ into phosphatase activity (Treseder \& Vitousek, 2001; Wang et al., 2007; Marklein \& Houlton, 2012). The N-stimulated phosphatase activity has particularly been observed in P-limited tropical ecosystems (Houlton et al., 2008). Even so, our study still showed that plant $\mathrm{P}$ concentration was significantly lower under elevated than ambient $\mathrm{N}$ levels (Fig. 1). This may be due to that $\mathrm{N}$-induced potential increase in $P$ availability is insufficient to balance the increasing $P$ requirement under $\mathrm{N}$ input. With excessive input of $\mathrm{N}$ to terrestrial ecosystems through human activity, the shift likely occurs from more $\mathrm{N}$ limitation to more $\mathrm{P}$ limitation for biomass production.

The second line of evidence for the aggravated $\mathrm{P}$ limitation under $\mathrm{N}$ enrichment is that P-induced increases in plant AGB and AGB : BGB ratios were larger under elevated than ambient $\mathrm{N}$ levels (Figs 2 and 4). For example, $\mathrm{P}$ significantly increased AGB and BGB in grassland under elevated $\mathrm{N}$ but not under ambient $\mathrm{N}$ (Fig. 2). The P-induced increases in AGB in wetland were larger $(44 \%)$ in elevated than ambient $(21 \%)$ (Fig. 2). Our results indicate that biomass production is more $\mathrm{P}$ limited under elevated than ambient $\mathrm{N}$ condition. Although Elser et al. (2007) reported similar results that simultaneous addition of $\mathrm{N}$ and $\mathrm{P}$ produced stronger impact on primary producers than they added alone, $\mathrm{P}$ effect sizes were not compared between the ambient and elevated $\mathrm{N}$ levels.

Phosphorus enrichment also can influence the rate of $\mathrm{N}$ fixation and increase $\mathrm{N}$ availability (Eisele et al., 1989; Crews et al., 2000). It has been showed that nitrogenase activity on leaf litter increased significantly after $\mathrm{P}$ addition in Hawaii tropical forests (Crews et al., 2000). Even so, there is not much evidence to indicate that $\mathrm{P}$ addition may increase ecosystem $\mathrm{N}$ availability. In this study, we found that $\mathrm{P}$ addition did not significantly change soil $\mathrm{N}$ availability (Fig. $\mathrm{7b}$ ) but decreased leaf $\mathrm{N}$ concentration, especially for herbaceous species (Figs 1 and S1).

\section{Factors influencing $P$ addition effects}

The effect sizes of $\mathrm{P}$ addition on biomass production vary with ecosystem types. Tropical forests had stronger responses in both AGB and BGB to added P than other ecosystems (Figs 2a and 3a). It supports the longheld notion that tropical ecosystems on old soil are predominantly P limited (Walker \& Syers, 1976; Cleveland et al., 2002; Elser et al., 2007). N addition reduced the positive $\mathrm{P}$ addition effect on biomass in tropical forests (Figs $2 \mathrm{~b}$ and $3 \mathrm{~b}$ ). This is probably due to that tropical forest is rich in $\mathrm{N}$ and extra $\mathrm{N}$ addition may exceed plant demand and constrain plant growth (Mo et al., 2008). Moreover, N addition can exacerbate soil acidification in tropical forest and thus had detrimental effects on plant growth (Tian \& Niu, 2015).

It is generally accepted that tundra was highly nutrient limited due to reduced availability of soil nutrients 
under low temperature (Sundqvist et al., 2013). Some studies have revealed strong effects of fertilization on plant biomass and community composition in tundra ecosystem (Bret-Harte et al., 2008; Tara \& Paul, 2012). However, our analysis did not show, on average of all the experiments, significant responses of biomass production in tundra to $\mathrm{P}$ addition, while $\mathrm{P}$ limitation for biomass production varies largely across studies in tundra. AGB of grassland did not significantly respond to $\mathrm{P}$ addition under ambient $\mathrm{N}$ but increased by $26 \%$ under elevated N. This may be due to that grassland is more limited by $\mathrm{N}$ than by $\mathrm{P}$ under ambient $\mathrm{N}$ levels.

Our results showed that $\mathrm{P}$ effects also varied with its application rates. P addition effect on AGB was largest at the application rate of $15 \mathrm{~g} \mathrm{~m}^{-2}$ or higher (Fig. 2a), and the response ratio of BGB increased with increasing $\mathrm{P}$ addition rate (Fig. 3a). Unlike biomass response that is saturating as $\mathrm{N}$ fertilization rate increases (Aber et al., 1998; Lovett \& Goodale, 2011), this study does not detect any saturation response of terrestrial biomass to $P$ addition.

$\mathrm{P}$ fertilizer forms and experimental periods also regulated $\mathrm{P}$ effects. $\mathrm{Ca}\left(\mathrm{H}_{2} \mathrm{PO}_{4}\right)_{2}$ had a significant impact on AGB, whereas $\mathrm{NaH}_{2} \mathrm{PO}_{4}$ fertilizer did not (Fig. 2). It is possible that other elements contained in $\mathrm{P}$ fertilizers regulate $\mathrm{P}$ effects (Kongshaug et al., 2000). $\mathrm{Ca}\left(\mathrm{H}_{2} \mathrm{PO}_{4}\right)_{2}$ fertilizer comprised of single superphosphate and triple superphosphate, which contain sulfur (S) and calcium (Ca) in commercial products. Single superphosphate has $11-12 \%$ of $\mathrm{S}$ and $18-21 \%$ of $\mathrm{Ca}$ in combination. Triple superphosphate has $1.5 \%$ of $\mathrm{S}$ and $15 \%$ of $\mathrm{Ca}$ (Kongshaug et al., 2000). The presence of $\mathrm{S}$ and $\mathrm{Ca}$ in $\mathrm{Ca}\left(\mathrm{H}_{2} \mathrm{PO}_{4}\right)_{2}$ fertilizer may facilitate plant growth because both nutrients are deficient.

\section{Predictors for the P-induced increases in biomass production}

The response ratio of biomass production is positively correlated with the response ratio of plant $P$ concentration and $\mathrm{N}: \mathrm{P}$ ratio $(P=0.005)$, but showed an insignificant correlation with the response ratio of soil $\mathrm{P}$ availability $(P=0.69)$ or soil $\mathrm{N}: \mathrm{P}$ ratio $(P=0.71)$ (Fig. 8). Thus, soil $\mathrm{P}$ availability is a poor predictor of $\mathrm{P}$ limitation. Yuan \& Chen (2012) demonstrated that fine root production increased with an average increase of soil $\mathrm{P}$ availability along natural gradients in tropical forest, grasslands, and wetlands, but not in boreal forests and tundra ecosystems. The increase of fine root may not necessary lead to larger biomass and thus may not be a reliable indicator of $\mathrm{P}$ limitation. The positive correlation of plant $\mathrm{P}$ concentration or $\mathrm{N}$ : $\mathrm{P}$ ratio with biomass responses suggests that plant $\mathrm{P}$ is a better indicator for $\mathrm{P}$ limitation than soil $\mathrm{P}$ availability.
Our synthesis showed a large decrease in plant N : P ratio with $\mathrm{P}$ addition (Fig. 6). In comparison, previous studies reported different results as to the flexibility of plant N : P ratio with nutrient availability. For example, Sistla \& Schimel (2012) held that the response of $\mathrm{N}$ : P to soil nutrient availability is limited while Chapin et al. (1990) documented that plant N : P is driven more by variation in $\mathrm{P}$ availability, irrespective of $\mathrm{N}$ availability. Still some others reported a highly speciesspecific change in plant $\mathrm{N}: \mathrm{P}$ in response to soil nutrient (Mayor et al., 2014). By synthesizing experimental results across all the $\mathrm{P}$ addition studies, this study reveals a global pattern of the flexibility of plant $\mathrm{N}: \mathrm{P}$ in response to soil $\mathrm{P}$ availability and its regulations on biomass productions.

In conclusion, this study, to our knowledge, is among the first global syntheses to quantitatively evaluate responses of ecosystem biomass production, plant and soil $\mathrm{P}$ concentration and $\mathrm{N}$ : $\mathrm{P}$ ratio to $\mathrm{P}$ addition. Our synthesis showed that $\mathrm{P}$ limitation was worldwide in natural ecosystem and was as strong as global $\mathrm{N}$ limitation for biomass production. P limitation became stronger under enriched $\mathrm{N}$ condition in most natural ecosystems, regardless the large variations in the effect size of $\mathrm{P}$ addition with ecosystem types, $\mathrm{P}$ fertilizer forms, and rates. $\mathrm{P}$ limitation was better indicated by plant $\mathrm{P}$ concentration and $\mathrm{N}$ : $\mathrm{P}$ ratio than soil $\mathrm{P}$ availability. The findings suggest a global $\mathrm{P}$ limitation in terrestrial ecosystems, which is likely aggravated by $\mathrm{N}$ deposition from fossil fuel combustion and agricultural fertilization.

\section{Acknowledgements}

We thank all the researchers whose data were included in this meta-analysis. This study was financially supported by National Natural Science Foundation of China (31290220, 41403073), Ministry of Science and Technology of China (2013CB956300) and Young Thousand Talents Project.

\section{References}

\footnotetext{
Aber J, Mcdowell W, Nadelhoffer K et al. (1998) Nitrogen saturation in temperate forest ecosystems. BioScience, 48, 921-934.

Agren GI (2008) Stoichiometry and nutrition of plant growth in natural communities. Annual Review of Ecology, Evolution and Systematics, 39, 153-170.

Benner JW, Vitousek PM (2007) Development of a diverse epiphyte community in response to phosphorus fertilization. Ecology Letters, 10, 628-636.

Bennett LT, Adams MA (2001) Response of a perennial grassland to nitrogen and phosphorus additions in sub-tropical, semi-arid Australia. Journal of Arid Environments, 48, 289-308

Braun S, Thomas VFD, Quiring R, Flückiger W (2010) Does nitrogen deposition increase forest production? The role of phosphorus. Environmental Pollution, 158, 2043-2052.

Bret-Harte MS, Mack MC, Goldsmith GR et al. (2008) Plant functional types do not predict biomass responses to removal and fertilization in Alaskan tussock tundra. Journal of Ecology, 96, 713-726.

Burman U, Garg BK, Kathju S (2009) Effect of phosphorus application on clusterbean under different intensities of water stress. Journal of Plant Nutrition, 32, 668-680.
} 
Chapin FS, Schulze E, Mooney HA (1990) The ecology and economics of storage in plants. Annual Review of Ecology and Systematics, 21, 423-447.

Cleveland CC, Townsend AR, Schmidt SK (2002) Phosphorus limitation of microbial processes in moist tropical forests: evidence from short-term laboratory incubations and field studies. Ecosystems, 5, 0680-0691.

Corbin J, Avis P, Wilbur R (2003) The role of phosphorus availability in the response of soil nitrogen cycling, understory vegetation and arbuscular mycorrhizal inoculum potential to elevated nitrogen inputs. Water, Air, and Soil Pollution, 147, $141-162$.

Crews TE, Farrington H, Vitousek PM (2000) Changes in asymbiotic, heterotrophic nitrogen fixation on leaf litter of metrosideros polymorpha with long-term ecosystem development in Hawaii. Ecosystems, 3, 386-395.

Crowley KF, Mcneil BE, Lovett GM et al. (2012) Do nutrient limitation patterns shift from nitrogen toward phosphorus with increasing nitrogen deposition across the northeastern United States? Ecosystems, 15, 940-957.

Davidson EA, Carvalho CJRD, Vieira ICG et al. (2004) Nitrogen and phosphorus limitation of biomass growth in a tropical secondary forest. Ecological Applications, 14, S150-S163.

Eisele KA, Schimel DS, Kapustka LA, Parton WJ (1989) Effects of available P-ratio and N-P ratio on non-symbiotic dinitrogen fixation in tallgrass prairie soils. Oecologia, 79, 471-474.

Elser JJ, Bracken MES, Cleland EE et al. (2007) Global analysis of nitrogen and phosphorus limitation of primary producers in freshwater, marine and terrestrial ecosystems. Ecology Letters, 10, 1135-1142.

Garg BK, Burman U, Kathju S (2004) The influence of phosphorus nutrition on the physiological response of moth bean genotypes to drought. Journal of Plant Nutrition and Soil Science, 167, 503-508.

Graciano C, Goya JF, Frangi JL, Guiamet JJ (2006) Fertilization with phosphorus increases soil nitrogen absorption in young plants of Eucalyptus grandis. Forest Ecology and Management, 236, 202-210.

Gress SE, Nichols TD, Northcraft CC, Peterjohn WT (2007) Nutrient limitation in soils exhibiting different nitrogen availabilities: what lies beyond nitrogen saturation? Ecology, 88, 119-130.

Güsewell S (2004) N: P ratios in terrestrial plants: variation and functional significance. New Phytologist, 164, 243-266.

Güsewell S, Koerselman W, Verhoeven JTA (2003) Biomass N: P ratios as indicators of nutrients limitation for plant populations in wetlands. Ecological Applications, 13, 372-384.

Harpole WS, Ngai JT, Cleland EE et al. (2011) Nutrient co-limitation of primary producer communities. Ecology Letters, 14, 852-862.

Hedges LV, Gurevitch J, Curtis PS (1999) The meta-analysis of response ratios in experimental ecology. Ecology, 80, 1150-1156.

Herbert D, Fownes J (1995) Phosphorus limitation of forest leaf area and net primary production on a highly weathered soil. Biogeochemistry, 29, 223-235.

Houlton BZ, Wang Y-P, Vitousek PM, Field CB (2008) A unifying framework for dinitrogen fixation in the terrestrial biosphere. Nature, 454, 327-330.

Huang W-J, Zhou G-Y, Liu J-X (2012) Nitrogen and phosphorus status and their influence on aboveground production under increasing nitrogen deposition in three successional forests. Acta Oecologica, 44, 20-27.

Kongshaug G, Brentnall BA, Chaney K et al. (2000) Phosphate fertilizers. In: Ullmann's Encyclopedia of Industrial Chemistry, pp. 1-49. Wiley-VCH Verlag GmbH \& Co. KGaA, Weinheim.

Lebauer DS, Treseder KK (2008) Nitrogen limitation of net primary productivity in terrestrial ecosystems is globally distributed. Ecology, 89, 371-379.

Lovett G, Goodale C (2011) A new conceptual model of nitrogen saturation based on experimental nitrogen addition to an oak forest. Ecosystems, 14, 615-631.

Mahowald N, Jickells TD, Baker AR et al. (2008) Global distribution of atmospheric phosphorus sources, concentrations and deposition rates, and anthropogenic impacts. Global Biogeochemical Cycles, 22, GB4026.

Marklein AR, Houlton BZ (2012) Nitrogen inputs accelerate phosphorus cycling rates across a wide variety of terrestrial ecosystems. New Phytologist, 193, 696-704.

Mayor J, Wright SJ, Schuur EG, Brooks M, Turner B (2014) Stable nitrogen isotope patterns of trees and soils altered by long-term nitrogen and phosphorus addition to a lowland tropical rainforest. Biogeochemistry, 119, 293-306.
Mo J, Zhang W, Zhu W, Gundersen P, Fang Y, Li D, Wang H (2008) Nitrogen addition reduces soil respiration in a mature tropical forest in southern China. Global Change Biology, 14, 403-412.

Olander L, Vitousek P (2000) Regulation of soil phosphatase and chitinase activity by $\mathrm{N}$ and $\mathrm{P}$ availability. Biogeochemistry, 49, 175-191.

Peñuelas J, Poulter B, Sardans J et al. (2013) Human-induced nitrogen-phosphorus imbalances alter natural and managed ecosystems across the globe. Nature Communications, 4, 2934.

Reich PB, Oleksyn J, Wright IJ (2009) Leaf phosphorus influences the photosynthesis-nitrogen relation: a cross-biome analysis of 314 species. Oecologia, 160, 207-212.

Schachtman DP, Reid RJ, Ayling SM (1998) Phosphorus uptake by plants: from soil to cell. Plant Physiology, 116, 447-453.

Sistla SA, Schimel JP (2012) Stoichiometric flexibility as a regulator of carbon and nutrient cycling in terrestrial ecosystems under change. New Phytologist, 196, 68-78.

Soudzilovskaia NA, Onipchenko VG, Cornelissen JHC, Aerts R (2005) Biomass production, N: P ratio and nutrient limitation in a Caucasian alpine tundra plant community. Journal of Vegetation Science, 16, 399-406.

Sundqvist MK, Liu Z, Giesler R, Wardle DA (2013) Plant and microbial responses to nitrogen and phosphorus addition across an elevational gradient in subarctic tundra. Ecology, 95, 1819-1835.

Suriyagoda LDB, Ryan MH, Renton M, Lambers H (2014) Plant responses to limited moisture and phosphorus availability: a meta-analysis. In: Advances in Agronomy (ed. Donald LS), pp. 143-200. Academic Press, New York, NY.

Tara JZ, Paul G (2012) Birch shrub growth in the low Arctic: the relative importance of experimental warming, enhanced nutrient availability, snow depth and caribou exclusion. Environmental Research Letters, 7, 034027.

Tian D, Niu S (2015) A global analysis of soil acidification caused by nitrogen addition. Environmental Research Letters, 10, 024019.

Townsend AR, Cleveland CC, Asner GP, Bustamante MMC (2007) Controls over foliar N: P ratios in tropical rain forests. Ecology, 88, 107-118.

Treseder KK, Vitousek PM (2001) Effects of soil nutrient availability on investment in acquisition of $\mathrm{N}$ and $\mathrm{P}$ in Hawaiian rain forests. Ecology, 82, 946-954.

Tyrrell T (1999) The relative influences of nitrogen and phosphorus on oceanic primary production. Nature, 400, 525-531.

Vitousek PM (2004) Nutrient Cycling and Limitation: Hawai'i as a Model System. Princeton University Press, Princeton, NJ.

Vitousek PM, Porder S, Houlton BZ, Chadwick OA (2010) Terrestrial phosphorus limitation: mechanisms, implications, and nitrogen-phosphorus interactions. Ecological Applications, 20, 5-15.

Walker TW, Syers JK (1976) The fate of phosphorus during pedogenesis. Geoderma, 15, 1-19.

Wang YP, Houlton BZ, Field CB (2007) A model of biogeochemical cycles of carbon, nitrogen, and phosphorus including symbiotic nitrogen fixation and phosphatase production. Global Biogeochemical Cycles, 21, GB1018.

Yuan ZY, Chen HYH (2012) A global analysis of fine root production as affected by soil nitrogen and phosphorus. Proceedings of the Royal Society of London B: Biological Sciences, 279, 3796-3802.

\section{Supporting Information}

Additional Supporting Information may be found in the online version of this article:

Figure S1. Response of leaf N concentration to P addition.

Table S1. Papers included in this study for establishing the database. 